\title{
MEDIATISASI DAKWAH, MORALITAS PUBLIK DAN KOMODIFIKASI ISLAM DI ERA NEOLIBERALISME
}

\author{
Arie Setyaningrum Pamungkas
}

\section{Abstrak}

Dakwah Islam bukan hanya ditujukan untuk menyampaikan pesan spiritual bagi pembentukan pribadi Muslim, melainkan juga ditujukan untuk suatu tujuan normatif, praktik moralitas publikyang didasarioleh interpretasi atas ajaran Islam tertentu. Perkembangan media telah memfasilitasi praktik dakwah, sejak masa kolonial dimana percetakan Al Qur'an bahkan ikut difasilitasi oleh pemerintah kolonial, hingga terbentuknya press Islam yang ikut mendorong munculnya nasionalisme sebagai bentuk resistensi, hingga bentuk-bentuk dakwah yang dimediasikan sehingga membentuk ranah publik Muslim. Keragaman medium dalam dakwah telah menciptakan ranah publik Muslim (Muslim public sphere) sehingga bukan hanya mampu menjadi basis terbentuknya konstituensi politik, bahkan pasar baru bagi identitas Muslim. Sengkarut antara kepentingan politis dan kapital ekonomi secara rentan mengubah muatan dakwah menjadi alat propaganda dan bahkan mampu menciptakan 'fandom' dimana komodifikasi Islam mengabdi pada logika pasar neoliberalisme. Inilah yang berlangsung di Indonesia selama dua dekade terakhir. Fenomena yang mentransformasi moralitas publik menjadi komoditas, baik sebagai komoditas politik maupun ekonomi ini juga sesungguhnya berlangsung secara global.

Kata kunci: mediatisasi dakwah, moralitas publik, transformasi media Islam, ranah publik Muslim, komodifikasi Islam, neoliberalisme 


\section{Mediatisasi Dakwah dan Moralitas Publik}

Mediatisasi dakwah berkenaan dengan bagaimana bentuk-bentuk dakwah dimediasikan. Bentuk-bentuk dakwah Islam yang dimediasikan (mediated da'wa forms) memiliki peran kunci dalam proses Islamisasi di Indonesia (Weintraub, 2011). Untuk memperoleh gambaran bagaimana proses Islamisasi difasilitasi oleh media, oleh karena itu yang perlu dipahami pertama-tama adalah bagaimana dakwah yang termediasikan ini mengalami transformasi secara historis mengikuti perubahan politik dan ekonomi di Indonesia bahkan yang ikut dipengaruhi oleh perubahan landskap ekonomi politik global. Hal penting yang juga perlu diperhatikan adalah bahwasannya keragaman media Islam secara historis di Indonesia mewakili keragaman berbagai organisasi Islam dan atau ideologi Islam tertentu. Oleh karena itu penting pula untuk menandai berbagai kepentingan asal mula bagaimana media Islam sebagai alat dakwah mempertemukan kepentingannya untuk menjangkau publik Muslim yang lebih luas dan oleh karena itu pula bersinggungan antara kepentingan ideologis dengan negara. Hal ini dikarenakan dakwah Islam bukan hanya ditujukan sebagai suatu panggilan yang bersifat individual bagi pembentukan kepribadian Muslim sesuai ajaran Islam, melainkan juga suatu tafsir sosial, ekonomi, politik bahkan strategi kebudayaan yang karenanya bersifat politis.

Dakwah secara umum dipahami pula sebagai misi Islam untuk mengamalkan 'amar ma'ruf nahi munkar' - menyuruh kepada kebajikan dan mencegah kemungkaran. Dalam konteks yang luas tafsir tersebut ditujukan pada upaya mengubah kepribadian individu Muslim menuju suatu tatanan masyarakat yang dianggap lebih Islami, sehingga dalam pengertian semacam ini maka dakwah Islam akan selalu memiliki tafsir yang bersifat politis. Ketika muatanmuatan dakwah kemudian dimediasikan dan menjangkau publik luas yang plural, maka konsekuensi moral atas muatan-muatan dakwah tersebut dapat bersifat problematis. Hal ini yang secara dramatis kita saksikan belum lama ini dalam kasus 'penistaan agama' yang dituduhkan kepada mantan gubernur DKI Jakarta Ahok dan secara sukses dikampanyekan oleh sekelompok ormas Islam melalui gerakan 'Aksi Bela Islam' sejak pertengahan tahun 2016 hingga 2017 yang lalu.

Moralitas publik sendiri setidaknya memiliki dua pengertian utama. Pertama sebagai suatu standar moral dan etis yang ditujukan pada suatu masyarakat. Kedua sebagai suatu bentuk tekanan sosial yang dilakukan untuk mendominasi standar moral dan etis melalui tertib sosial dan bentuk-bentuk kedisiplinan serta kepatuhan publik (baik melalui regulasi formal maupun informal - tak tertulis) 
yang acapkali justru muncul sebagai suatu respon atas 'kepanikan moral'. Retorika kepanikan moral melalui praktik dakwah yang dimediasikan acapkali menggunakan doktrin Islam tentang 'amr ma'ruf nahi munkar' - 'menyuruh pada kebaikan dan mencegah perbuatan jahat' - yang dalam penerjemahannya juga bisa menjadi sangat politis dan menjadi riskan atas klaim terhadap 'kepatutan dan kelayakan' dalam masyarakat yang majemuk (plural) dan beragam (multikultur), bukan hanya antara Muslim dan non-Muslim, tetapi juga di antara masyarakat Muslim sendiri yang juga beragam. Bentuk-bentuk keshalehan dalam tafsir Islam yang dianggap sebagai sesuatu yang terlarang secara umum disepakati bersama sebagai suatu bentuk kontrol sosial misalnya, perjudian, prostitusi, konsumsi atas alkohol, dan pornografi atau materi-materi seksual yang bersifat eksplisit. Meski demikian, bukan berarti tafsir atas 'amr ma'ruf nahi munkar' tetap selalu menjadi persoalan dilematis di kalangan komunitas Muslim sendiri yang beragam, khususnya ketika klaim terhadap bentuk kepatuhan tertentu harus berhadapan dengan struktur kekuasaan politik. Hal ini nampak misalnya dalam upaya 'konstruksi atas moralitas publik' yang memunculkan polemik seperti dalam sosialisasi Rancangan Undangundang Pornografi dan Pornoaksi, yang kemudian disahkan sebagai UU Pornografi pada tahun 2008. Dalam polemik tersebut, pewacanaan mengenai 'pornografi dan pornoaksi' sudah jauh sebelumnya disebarkan melalui mediamedia dakwah tertentu, yang bahkan pada awalnya jauh dari perhatian publik luas di Indonesia. Majalah Ummi misalnya, suatu majalah yang berbasis pada gerakan Tarbiyah dan meskipun tidak secara langsung berafiliasi formal pada partai dakwah, PKS, setidaknya secara rutin telah memunculkan wacana tentang apa itu 'pornoaksi' - jauh sebelum munculnya RUU Pornografi tersebut disosialisasikan kepada publik mulai tahun 2005 (Pamungkas, 2015). Kepanikan moral acapkali bukan sesuatu yang muncul sebagai suatu konsekuensi sosial melainkan juga sebagai bagian dari kepentingan yang bersifat politis, termasuk yang terjadi dalam polemik mengenai UU Pornografi tahun 2008 tersebut. Bentuk kepanikan moral yang cukup dramatis melalui dakwah yang dimediasikan sebagai alat propaganda politik pada kasus penistaan agama yang dituduhkan kepada Ahok dan memunculkan gerakan protes 'Aksi Bela Islam' di tahun 2016. 


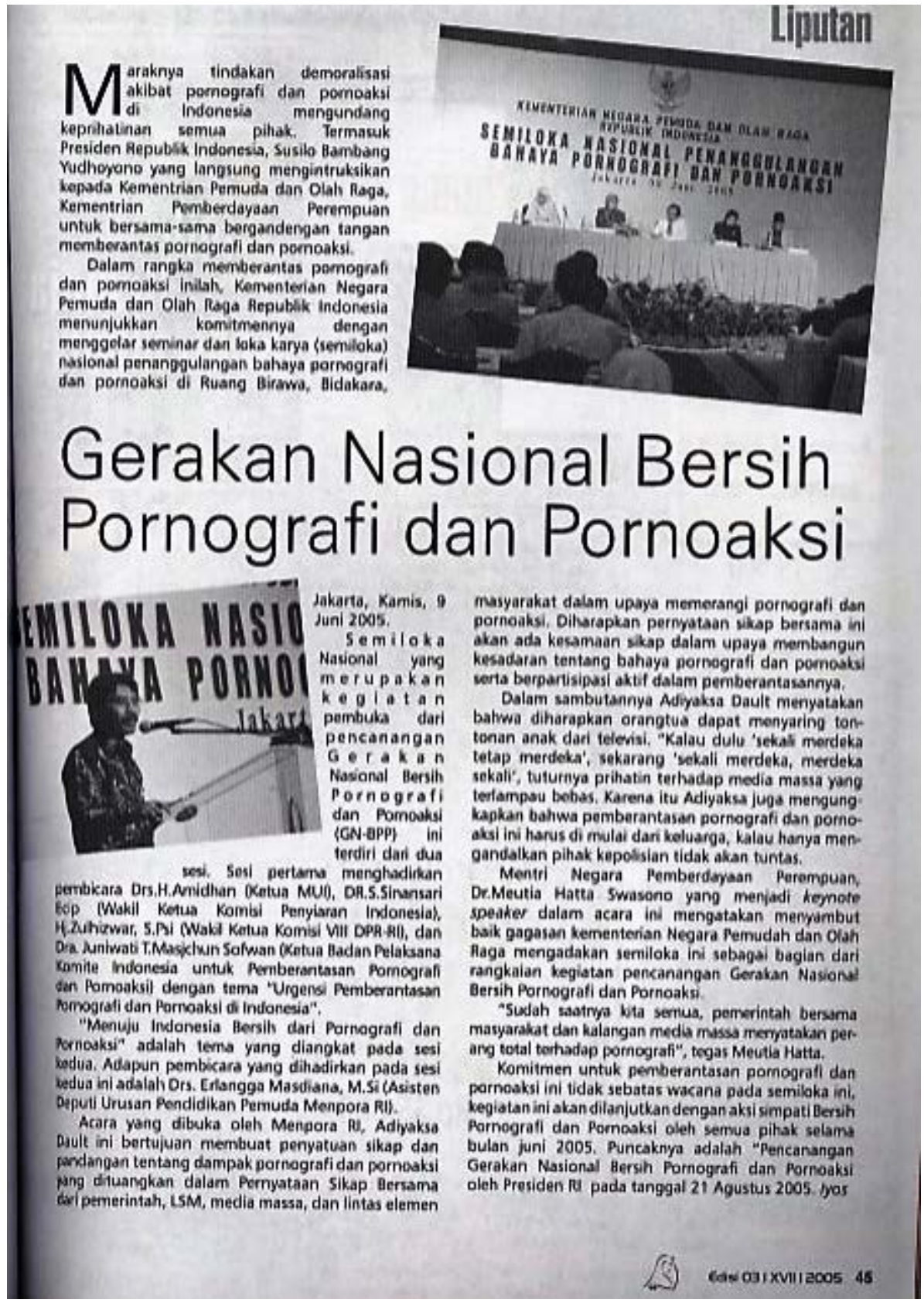

Gambar 9. Reportase Majalah Ummi No 3/XVII/2005 tentang 'Gerakan Nasional Bersih Pornografi dan Pornoaksi' yang dibuka oleh Menteri Pemuda dan Olahraga Adyaksa Daud pada tahun 2005 (Sumber: Pamungkas, 2015; Pamungkas, 2017).

Perhatian pada bentuk-bentuk moralitas publik yang menjadi bagian dari dakwah Islam itu sendiri pun rentan menjadi alat propaganda politik. Hal semacam ini 
membuka ruang kekuatiran dimana tema yang mengkaitkan moralitas publik juga dapat menjadi sumber bagi pertarungan kepentingan politik, bahkan dalam konteks tertentu menantang otoritas politik yang memiliki legitimasi. Meski demikian, kondisi semacam ini sebenarnya bukan sesuatu yang baru dalam sejarah politik Indonesia, bahkan termasuk kepentingan Islam politik yang dimediasikan melalui media di Indonesia. Persoalannya kini menjadi jauh lebih kompleks di era digital melalui teknologi keragaman media baru, yakni ketika 'dakwah yang dimediasikan' itu memiliki kemampuan untuk memobilisasi publik bagi kepentingan tertentu baik sebagai alat budaya promosi (promotional culture) maupun sebagai alat propaganda politik. Media baru memiliki kemampuan dalam mempercepat mobilisasi dukungan publik dan bahkan memperluas ekskalasi isu-isu tertentu yang secara sensitif dan emosional dikemukakan pada khalayak luas khususnya melalui pembingkaian wacana mengenai 'moralitas Islam'. Secara khusus, ini dicontohkan oleh media Islam yang dihasilkan oleh aktivisme Islam di era pasca Suharto ketika demokrasi liberal telah dipraktekkan lagi. Keberadaan Islam politik (Islamisme)yang selama lebih dari tigapuluh tahun beroperasi melalui jaringan 'underground'karena tekanan rezim terhadap bentuk-bentuk Islam politik menyeruak kembali secara terbuka ke publik sejak jatuhnya rezim Suharto di tahun 1998. Meskipun sesungguhnya, tekanan terhadapbentuk ekspresi Islam politik (Islamisme) justru dimulai di masa pemerintahan demokrasi terpimpin dibawah Sukarno khususnya sejak akhir 1950-an hingga pertengahan 1960-an khususnya ketika Partai Masyumi dibubarkan karena tuduhan terlibat dalam gerakan kudeta PRRI pada tahun 1960 (Madienier, 2015; Pamungkas, 2017).

Secara historis, kontestasi perubahan politik di Indonesia berdampak pada bagaimana dakwah dipraktikkan khususnya yang ikut melahirkan media Islam. Press Islam yang berakar pada zaman kolonial ikut menjadi bagian dari gerakan sosial politik sebagai alat perlawanan terhadap kolonialisme dan yang kemudian bahkan ikut membentuk nasionalisme. Peranan media massa Islam sebagai sarana pembentukan nasionalisme kemudian berlanjut di masa periode awal pascakolonial. Sementara itu di masa Orde Baru, bentuk-bentuk dakwah yang dimediasikan secara resmi justru difasilitasikan oleh pemerintah menjadi bagian dari upaya rezim untuk memperoleh dukungan dalam menjalankan pembangunan dan program-program pemerintah khususnya dari komunitaskomunitas Muslim terbesar di Indonesia seperti NU dan Muhammadiyah. Kompleksitas industri media di bawah modus kapitalisme juga berdampak pada bagaimana dakwah Islam berlangsung bukan hanya sebagai cara mempopulerkan 
ajaran Islam, melainkan lebih jauh lagi membentuk pasar baru bagi identitas Muslim. Munculnya rezim Orde Baru dengan naiknya Suharto ke tampuk kekuasaan pasca 1965 menjadi momentum penanda penting di mana industri budaya populer mendapatkan ruang yang lebih leluasa bagi terbentuknya pasar industri hiburan di Indonesia, termasuk yang ditujukan bagi konsumsi kesalehan agama, khususnya Islam.

Promosi awal kesalehan Islam pada masa Orde Baru justru menyediakan pondasi ranah baru Islamisasi, terutama ketika praktik dakwah bertemu dengan mode produksi kapitalis melalui industri media dan mengubah praktik dakwah menjadi budaya populer. Pada masa Orde Baru pula gairah semangat untuk menyemai identitas Islam justru muncul dari kalangan kelas menengah urban berpendidikan. Hal ini menjadi tantangan tersendiri bagi otoritas keagamaan yang telah mapan melembaga sejak masa kolonial, seperti Muhammadiyah dan Nadhatul Ulama. Hasrat kelas menengah untuk menjadi 'Muslim yang lebih sempurna' justru menyemai ranah baru dimana ajaran dan tafsir-tafsir Islam mulai dikomodifikasikan. Lebih jauh lagi, pelayanan dan simbol kesalehan personal menjadi daya tarik utama dalam mengembangkan industri budaya pop Islami yang selama hampir dua dekade pasca Orde Baru semakin mapan dan semakin meluas pasarnya. Hal ini tentu mengubah landskap sosial dan budaya masyarakat Indonesia, khususnya ketika simbol-simbol dan praktik-praktik Islam tertentu secara hegemonik menjadi ranah yang dikuasai pula oleh kehendak pasar bebas di mana logika neoliberalisme membolehkan konsumerisme budaya dilakukan untuk kepentingan pencapaian keuntungan (profit) maksimal dan kepuasan identitas diri yang menjadi tujuan dari konsumsi itu sendiri. Budaya pop Islami yang terus berlanjut secara hegemonik di era pasca Suharto dalam kenyataannya juga dibentuk oleh berbagai ideologi gerakan dakwah global khususnya oleh ideologi Wahabi-Salafisme. Hal ini dimungkinkan melalui globalisasi di mana periode gerakan dakwah khususnya yang dimulai di masa Orde Baru telah mengekspansi kebutuhan menjadi Muslim yang sempurna dan memapankan 'identitas Islami' kelas menengah berpendidikan di lembaga-lembaga sekuler seperti perguruan-perguruan tinggi nasional. Gerakan dakwah yang dimulai semenjak akhir tahun 1970an di kampus-kampus sekuler telah mereproduksi suatu pola-pola pelembagaan dakwah yang menggantikan otoritas kelembagaan agama Islam yang sebelumnya telah mapan. Antusiasme memapankan identitas Islami ini justru difasilitasi oleh generasi yang justru memperoleh pengetahuan mengenai Islam melalui training-training dakwah di kampus-kampus sekuler. Dari sinilah Islamisme populer muncul dan hadir sebagai daya tarik gairah 
Muslim kelas menengah urban dan memperoleh kesempatan untuk semakin memperluas pemirsanya dalam reproduksi sosial dan ekonomi yang difasilitasi oleh logika ekonomi neoliberal kapitalisme.

\section{Transformasi Media Islam dan Ranah Publik Muslim di Indonesia (dari Konstituensi Politik ke Pasar Identitas Muslim) ${ }^{1}$}

Sejarah perkembangan media Islam di Indonesia berkenaan dengan persebaran dakwah atau ajakan untuk mengenal, mempelajari dan mempraktikkan ajaran Islam yang ditujukan secara khusus bagi kaum Muslim dan secara umum kepada khalayak luas atau publik. Meskipun pemahaman mengenai media Islam secara umum dipahami sebagai media yang mengutamakan identitas Islam, akan tetapi di dalam menampilkan muatannya berlangsung diskursus atau pewacanaan mengenai apakah muatan dakwah tersebut secara spesifik ditujukan pada komunitas yang secara spesifik telah dimiliki oleh media tersebut, ataukah ditujukan kepada khalayak umum. Pemahaman mengenai dakwah karenanya bisa bersifat luas sekaligus dapat bersifat spesifik. Dengan kata lain, semua media dakwah dapat disebut sebagai 'media Islam' meskipun tidak semua media yang memunculkan identitas keislaman dapat disebut sebagai media 'dakwah' dikarenakan upaya untuk menampilkan muatan dakwah itu sendiri berkenaan dengan konstruksi mengenai apakah dakwah itu sendiri hanya merupakan suatu promosi kesalehan diri ataukah sebagai suatu bagian dari perjuangan ideologi politik.

Dalam praktiknya, dakwah Islam berkembang secara pesat khususnya ketika teknologi mesin cetak berkembangdi dunia sejak abad ke 17, sebagaimana agama-agama samawi (Abrahamian) lainnya. Persebaran pengetahuan mengenai agama (termasuk Islam) mengalami periode modernisasi yang amat pesat. Al Qur'an misalnya mulai dicetak dalam jumlah yang cukup besar di Singapura sejak tahun 1840an dan pendistribusiannya juga menjangkau wilayah koloni Hindia Belanda (Indonesia sekarang). Hal ini berdampak pada tumbuh pesatnya sekolah-sekolah Islam tradisional (pesantren) di Nusantara, di mana sebelumnya tradisi mewarisi melafalkan al Qur'an lebih merupakan budaya 'mendengarkan' (auditory culture) mulai mapan menjadi budaya 'membaca' yang sekaligus menandai transformasi budaya visual dalam praktik dakwah yang menjangkau

1 Sebagian pemaparan mengenai sejarah singkat perkembangan media Islam dalam bagian ini pernah dipublikasikan penulis dalam artikel lain (Pamungkas, 2017. "Membela Islam? Dakwah, Konstruksi Moralitas dan Ruang Publik Muslim dalam Sejarah Media Islam di Indonesia." Dalam Sri Margana et.al (eds). 2017. Agama dan Negara di Indonesia: Pergulatan Pemikiran dan Ketokohan /Prosiding Seminar Sejarah Nasional 2017. Yogyakarta: Penerbit Ombak) 


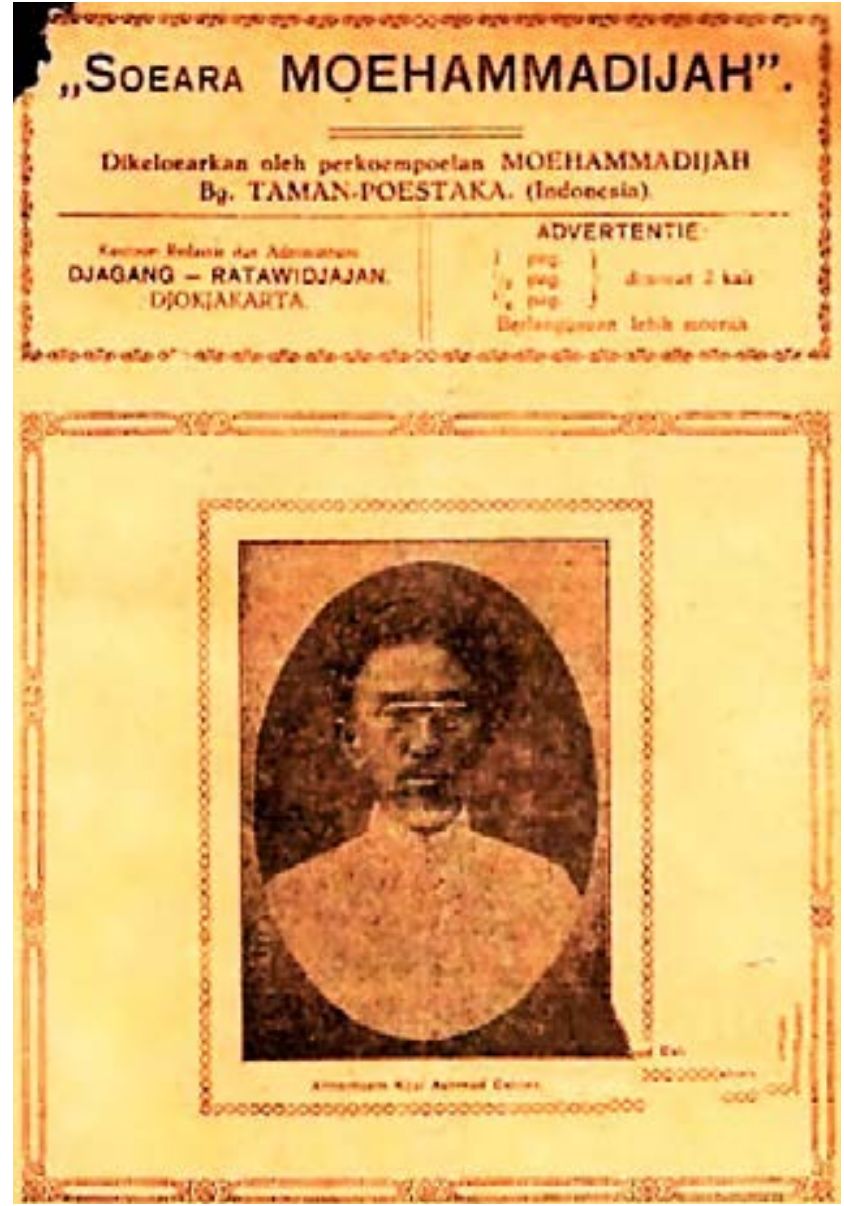

Gambar 10. Contoh Sampul Majalah Suara Muhammadiyah (Soera Muhammadijah) terbit tahun 1924, berisi tentang bagaimana mempraktikkan ajaran Islam dan bentuk-bentuk ibadah dalam Islam (Sumber: Disalin dari Arsip Suara Muhammadiyah, 2017)

Muslim kebanyakan dan karenanya menjadi medium dakwah yang efektif. Maraknya percetakan kitab-kitab suci (termasuk al Qur'an) berbarengan dengan munculnya pertumbuhan industri percetakan untuk kepentingan munculnya pers cetak media massa untuk pertama kalinya di wilayah Asia Tenggara. Pada gilirannya, kemunculan media cetak inilah yang turut melahirkan media massa termasuk 'press Islam' dan mentransformasi kehidupan sosial, politik, ekonomi dan budaya di hampir seluruh wilayah jajahan di Hindia Belanda. Keberadaan industri percetakan ikut memfasilitasi penerbitan beberapa bukubuku (kitab) yang mengenalkan identitas keislaman melalui genre syair (puisi) dan hikayat (prosa) dalam bahasa Melayu untuk pertama kalinya. Ini misalnya ditandai dengan penerbitan Jurnal al-Moenir pada tahun 1910-1915 di Padang, 
Sumatera Barat. Dakwah kemudian disampaikan pula melalui metode transmisi nilai-nilai dan konstruksi atas identitas keislaman. Pertumbuhan industri cetak dan munculnya minat membaca di wilayah koloni juga turut mendorong penerbitan-penerbitan pers Islam di mana dakwah dikonstruksikan sebagai semangat untuk melawan bentuk-bentuk penindasan kolonialisme, misalnya oleh surat kabar Medan Moeslimin yang terbit pada tahun 1915, dan kemudian munculnya Islam Bergerak pada tahun 1917.

Konstruksi dakwah sebagai suatu alat perjuangan politik nasionalisme ini dipelopori oleh salah satu pendiri Syarekat Islam, Haji Misbach, yang menggabungkan nilai-nilai sosialisme dan ajaran-ajaran Islam untuk melawan penindasan sebagai basis identitas kebangsaan (nasionalisme) sekaligus sebagai wujud keshalehan seorang Muslim. Di sisi lain, persebaran ideologi 'revivalisme (kebangkitan) Islam' yang bersifat transnasional juga muncul di masa kolonial, misalnya pada tahun 1930 terbit 'Madjalah Pembela Islam' yang didirikan oleh ulama PERSIS (Persatuan Islam) di Bandung, Ahmad Hasan dan muridnya, Muhammad Natsir (yang kemudian dikenal sebagai tokoh Masyumi). Gagasangagasan yang disampaikan melalui penerbitan ini memiliki kemiripan dengan gagasan Ikhwanul Muslimin di Mesir yang digagas oleh Hasan al-Banna yang menganjurkan pentingnya persatuan kaum Muslimin yang dijajah di seluruh wilayah kolonial Barat melalui pendidikan dan pengorganisasian politik. Di masa pergerakan nasional, bentuk-bentuk dakwah yang dimediasikan melalui penerbitan cetak secara berkala untuk membangun komunitas ditunjukkan oleh beberapa penerbitan, misalnya Suara Muhammadiyah, Al Muslimun, dan Kiblat. Di masa pendudukan Jepang, pers nasional mengalami represi yang lebih berat ketimbang di masa pemerintahan kolonial Hindia Belanda, hal yang serupa juga dialami dengan eksistensi beberapa penerbitan Islam. Suara Muhammadiyah adalah salah satu contoh majalah Islam berbasis komunitas yang masih bertahan mampu terbit relatif secara reguler pada masa pendudukan Jepang (1942-1945).

Pada masa awal kemerdekaan keberadaan dakwah Islam juga dimanfaatkan untuk membangun konstituensi politik. Hal ini misalnya ditunjukkan oleh penerbitan yang berafiliasi dengan partai politik, misalnya Masyumi. Partai Masyumi memiliki penerbitan majalah Suara Partai Masyumi, majalah Hikmah dan surat kabar Abadi. Menjelang dan setelah Pemilu pertama pada tahun 1955 misalnya, penerbitan ini banyak mengkritik PKI dan ideologi MarxismeLeninisme. Pada tahun 1958 beberapa tokoh Masyumi dituduh telah ikut merencanakan makar kudeta terhadap pemerintahan Sukarno karena terlibat 
di dalam peristiwa PRRI/Permesta sehingga pada tahun 1960 partai ini dibubarkan oleh pemerintah Sukarno. Hal ini berdampak pula pada berakhirlnya penerbitan-penerbitan yang berafiliasi secara langsung pada partai Masyumi. Sebagian aktivis Masyumi yang memiliki kedekatan dengan Muhammadiyah seperti Hamka (Haji Abdul Malik Karim Amrullah), KH. Faqih Usman, Josoef Abdullah Poear, dan HM Joesof Ahmad menjelang dibubarkannya partai Masyumi mendirikan penerbitan majalah Panji Masyarakat pada tahun 1959. Meskipun cukup populer sebagaimana penerbitan Masyumi sebelumnya, majalah ini di masa itu hanya terbit selama 1 tahun dan kemudian dibredel (dilarang terbit) oleh pemerintah setelah terbitnya tulisan Mohammad Hatta 'Demokrasi Kita' yang mengkritik model otokratis 'demokrasi terpimpin' a la Sukarno pada bulan Mei 1960. Majalah Panji Masyarakat baru muncul kembali setelah terjadi pergantian kekuasaan ke tangan rezim Orde Baru (Suharto). Peralihan kekuasaan di tangan rezim Orde Baru pasca 1965 berdampak pada kontrol kekuasaan yang ketat terhadap penerbitan media massa, termasuk pada pers Islam. Ideologi Islam politik bahkan sama sekali tidak memperoleh ruang gerak sehingga beberapa tokoh eksponen Masyumi terutama yang dipelopori oleh Mohammad Natsir memilih untuk menghindari konfrontasi langsung dengan rezim Suharto dan merintis jalan 'dakwah' melalui organisasi massa seperti DDII - Dewan Dakwah Islamiyah Indonesia. Semenjak tahun 1970 an hingga akhir 1980-an, kegiatan DDII berkaitan dengan memfasilitasi penerbitan buku, majalah, dan terutama penerjemahan beberapa literatur dari Timur-Tengah seperti literatur yang ditulis oleh tokoh-tokoh Ikhwanul Muslimin ke dalam bahasa Indonesia. DDII bahkan memiliki majalah reguler 'Media Da'wah' - yang diterbitkan secara berkala dan menjadi perpanjangan corong politik Masyumi di era Orde Baru. Melalui kegiatan dakwahnya pula DDII turut secara tidak langsung ikut membangun jaringan para aktivis dakwah kampus yang kemudian dikenal sebagai gerakan Tarbiyah sejak akhir 1970-an dan puncaknya di tahun 1990-an di beberapa kampus-kampus perguruan tinggi nasional.

Di masa Orde Baru gagasan-gagasan 'revivalisme Islam' tidak dikontestasikan secara terbuka tetapi memperoleh persemaian melalui kegiatan training dakwah di kampus-kampus oleh para kader aktivis dakwah kampus. Disis lain, ketika kekuasaan Suharto mulai menampakkan kecenderungan menurunnya dukungan dari militer, rezim ini semenjak tahun 1990-an mulai merangkul beberapa intelektual Muslim liberal yang ditunjukkan melalui dukungan atas pembentukan ICMI (Ikatan Cendekiawan Muslim Indonesia). Budaya promosi 
kesalehan individu memperoleh representasinya termasuk di dalam mediamedia yang menggunakan identitas Islam di masa Orde Baru. Hal ini misalnya ditunjukkan oleh majalah Amanah di masa Orde Baru, yakni khususnya ketika kalangan tokoh-tokoh Muslim dan khususnya MUI memberi dukungan bagi program-program yang dilakukan oleh pemerintah, misalnya untuk program Keluarga Berencana (KB) (Gambar 11)

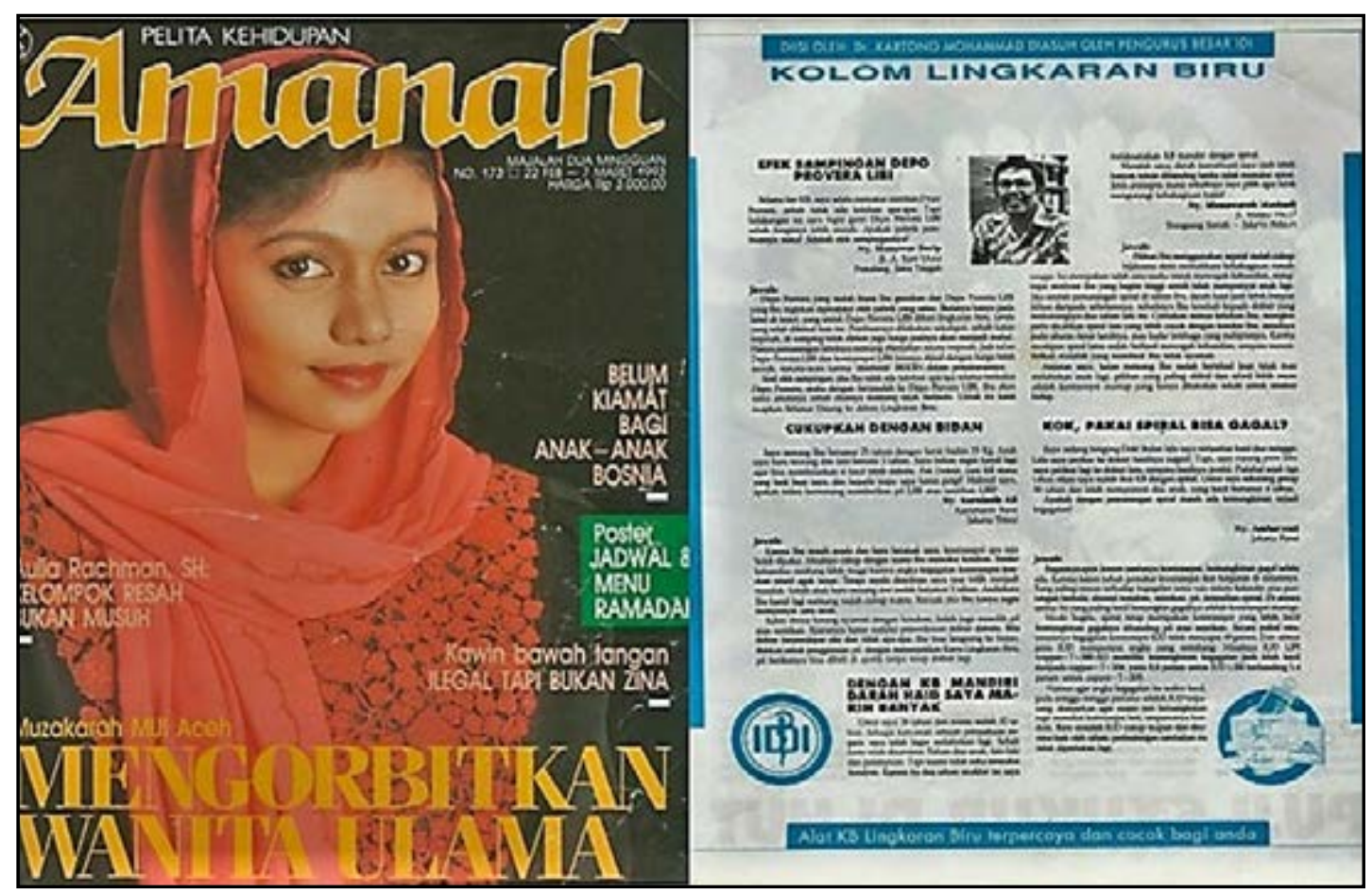

Gambar 11. Majalah Amanah di masa Orde Baru dan dukungan pada program pemerintah (Sumber: Pamungkas, 2015; Pamungkas, 2017).

Runtuhnya kekuasaan Orde Baru pada tahun 1998 memulai suatu era di mana demokrasi liberal dipraktikkan kembali di Indonesia (setelah sebelumnya pernah dipraktikkan pada 1955-1958). Kesempatan untuk mempopulerkan gagasan Islam transnasional pada publik luas justru mulai tumbuh pada periode ini. Hal ini didukung oleh kemudahan ijin penerbitan di masa pemerintah BJ Habibie pada tahun 1999. Beberapa media Islam yang menyuarakan tema-tema mengenai jihad pun muncul dan beredar luas di masyarakat. Pada gilirannya, perkembangan teknologi informasi dan komunikasi juga turut memfasilitasi munculnya beberapa penerbitan Islamisme populer secara daring (online) melalui media-media digital di awal abad millenium. Keberadaan media Islam 
sebagai alat dakwah di Indonesia telah menciptakan apa yang disebut oleh Eickelman dan Anderson (2003) sebagai 'ranah publik Muslim' (Muslim public sphere) di mana berlangsung suatu kontestasi terbuka atas otoritas menggunakan bahasa normatif yang secara simbolik mengatasnamakan Islam. Fenomena munculnya 'ranah publik Muslim' juga merupakan wujud'reintelektualisasi wacana-wacana Islam' di mana pengirim pesan (sender) mengidentifikasikan diri mempresentasikan doktrin dan wacana Islam yang otentik (murni) dan interpretasi atasnya pada publik (receiver). Pewacanaan Islam otentik dapat pula dianggap sebagai suatu bentuk hegemoni tanding (counter hegemony) di mana identitas modern justru dilekatkan dengan simbol dan formalisme agama (Islam) melalui produksi kapitalisme melalui budaya konsumsi yang bertujuan untuk pemuasan diri. Bentuk-bentuk gagasan mengenai identitas Islam yang dimediasikan melalui media baru menjelaskan bagaimana sesungguhnya proses 'Islamisasi' di Indonesia sejak masa Orde Baru hingga di masa Reformasi ditujukan justru pada kebanyakan 'Muslim' (“mengIslamkan kembali orang Islam”). Proses Islamisasi ini berkenaan dengan pendisiplinan melalui wacanawacana Islamisme populer mulai dari pembentukan karakter yang secara monolitik merepresentasikan ideologi Wahabi-Salafisme tentang 'bagaimana mempraktikkan Islam yang benar.' Obyektifikasi atas praktik Islam yang otentik inilah yang kemudian menjadi ranah produksi media dakwah khususnya di masa Reformasi di mana ide-ide 'revivalisme Islam' muncul justru dimunculkan melalui konstruksi atas 'moralitas publik'. Konstruksi atas moralitas publik ini meregulasi kebiasaan hidup, tingkah laku, dan tertib sosial. Obyektifikasi atas 'Islam yang otentik' karenanya menjadi perdebatan bahkan perseteruan yang tiada hentinya hingga hari ini.

\section{Mediatisasi Dakwah dan Propaganda Islamisme Populer dalam Kasus Aksi Bela Islam}

Kontroversi penistaan agama yang dituduhkan kepada Ahok bermula melalui suatu versi singkat video yang diedit berisi tentang mengenai ceramah Ahok yang mengutip Surah Al Maidah Ayat 51 melalui media sosial Facebook yang diunggah oleh seorang netizen Buni Yani pada tanggal 6 Oktober 2016. Kontroversi inilah yang kemudian berkembang melalui gelombang protes Aksi Bela Islam. Kemampuan media sosial untuk melakukan komunikasi interaktif menjelaskan mengapa mobilisasi massa secara efektif diorganisir dalam protes massa melalui Aksi Bela Islam. Dalam aksi ini konstruksi atas moralitas publik untuk "membela Islam" tidak hanya mencakup kasus penodaan 
agama, tetapi juga sebagai strategi dakwah yang mendasari kode moral dan etis atas kesalehan Islam di Indonesia saat ini. Protes massa Aksi Bela Islam mendapatkan momentum puncaknya dalam bentuk shalat Jumat di lapangan Monumen Nasional (MONAS) Jakarta pada tanggal 2 Desember 2016 yang diselenggarakan oleh GNPF-MUI dan kemudian dikenal sebagai 'Aksi 212. Peristiwa Aksi 212 telah menunjukkan kemampuan penyelenggara (organizers) untuk memobilisasi sentimen 'keagamaan' yang secara efektif dibungkus sebagai isu moralitas publik sebagai suatu isu kepentingan nasional. Bahkan, sentimen agama dalam pengertian ini dibingkai melalui perangkat retoris yang secara khusus melayani kepentingan politik partisan tertentu. Hal ini nampak karena aksi ini juga didukung oleh partai-partai oposisi politik (misalnya: PKS atau Partai Keadilan dan Sejahtera dan Gerindra atau Agung Pesta Gerakan Indonesia) yang berkompetisi melawan Ahok atau Basuki Tjahaja Purnama sebagai incumben dalam pemilihan Gubernur Jakarta.

Wacana tentang membela Islam bukanlah sesuatu yang baru di Indonesia dan itu tidak hanya terjadi pada saat komunitas Muslim yang lebih luas dapat mengakses berbagai informasi melalui perkembangan teknologi media dan internet. Dalam kasus 'aksi untuk membela Islam’ misalnya, wacana tentang 'membela Islam' juga dibingkai oleh wacana lain tentang 'persatuan umat Islam Indonesia'. Wacana tersebut ditujukan untuk memenuhi dua strategi politik; yang pertama ditujukan untuk kepentingan politik jangka pendek dan yang kedua ditujukan untuk kepentingan politik jangka panjang. Strategi politik pertama dilakukan dengan membingkai kasus Ahok sebagai dorongan moral politik dengan mengekspresikan rasa saleh untuk membela Al-Qur'an, Ulama, dan dengan demikian bergabung dengan protes keagamaan. Strategi politik kedua tidak hanya bertujuan untuk memenjarakan Ahok, tetapi juga upaya untuk mempertahankan dukungan massa dengan secara kontroversial membingkai wacana perlunya kesatuan umat Islam Indonesia. Dalam strategi politik pertama dan kedua, wacana-wacana disebarluaskan dalam bentuk-bentuk retoris tertentu yang mencakup teks dan materi visual dengan memanfaatkan media teknologi digital termasuk kampanye di media sosial, dan dengan membangun jaringan pada tingkat akar rumput dengan mengkonsolidasikan massa melalui komunitas-komunitas.

Beberapa minggu sebelum Aksi 212 di lapangan Monas Jakarta pada awal Desember 2016, misalnya gerakan ini berupaya membangun jaringan di tingkat komunitas melalui 'Gerakan Nasional untuk Sholat Subuh Berjamaah'. Dengan memanfaatkan medium melalui praktik ibadah kepentingan politik 
dalam Aksi Bela Islam dikaburkan untuk mengesankan kepada publik bahwa gerakan tersebut secara visual tidak bersifat memaksa atau tidak dilakukan melalui kekerasan secara fisik sebagaimana yang sebelumnya muncul dalam Aksi Bela Islam pada tanggal 4 November 2016. Hal yang perlu dicermati pasca Aksi 212 adalah bagaimana gerakan ini bukan hanya bertujuan untuk membangun jaringan massa secara nasional melainkan juga membentuk suatu 'fandom' (penelisik - penggemar atau fans) Islamisme populer bagi reproduksi ekonomi yang muncul sebagai dampak keuntungan melalui mediatisasi dakwah Aksi Bela Islam. Dengan kata lain, Aksi Bela Islam telah menunjukkan bahwa sentimen agama sangat berpengaruh dalam memobilisasi tidak hanya untuk kepentingan politik jangka pendek seperti dalam kasus penistaan agama, tetapi juga pengkondisian budaya yang mempromosikan kode moral tertentu yang secara spesifik didiktekan oleh kelompok-kelompok Islamis bagi masyarakat Muslim di Indonesia untuk diterima. Kode moral ini terutama berkenaan dengan otoritas untuk merujuk kepada siapa yang paling boleh menentukan apa-apa saja yang dapat disebut sebagai penistaan terhadap Islam.

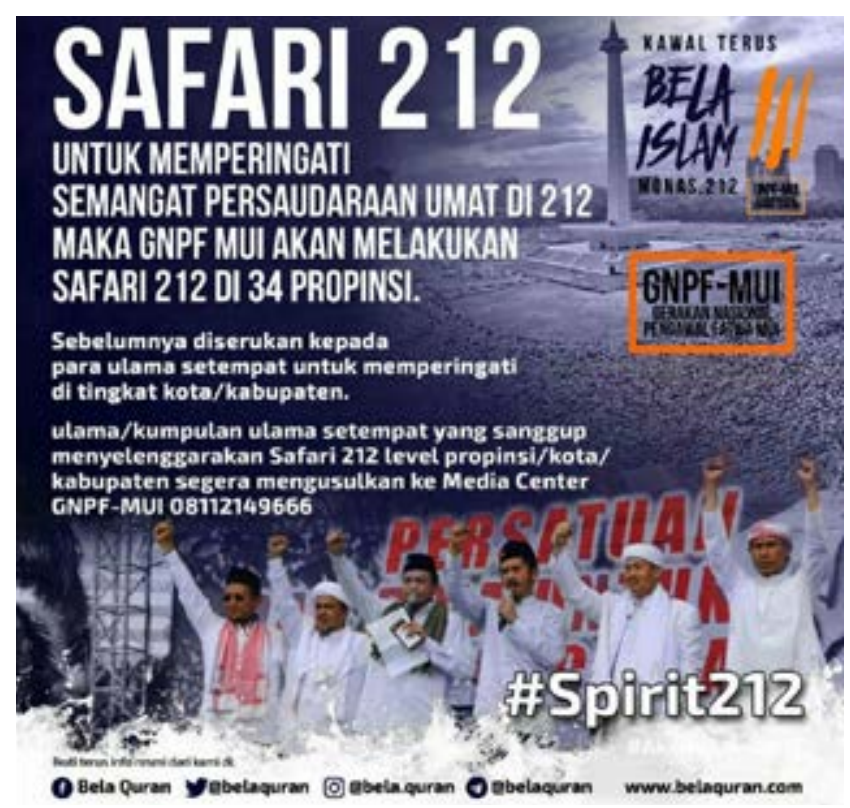

Gambar 12. Poster iklan Safari 212 yang disebarluaskan kepada publik melalui akun-akun media sosial milik GNPF-MUI dengan menggunakan hashtag (\#) Bela Quran. Hashtag adalah suatu bentuk atau cara pelekatan metadata dalam mesin pencarian materi media sosial di internet sehingga dapat dengan mudah ditemukan. 
Pengkondisian moralitas melalui Aksi Bela Islam secara paksa yang bahkan diterima secara sukarela oleh sebagian masyarakat Muslim di Indonesia ini pada gilirannya mempengaruhi lanskap politik, sosial dan ekonomi masyarakat Indonesia yang beragam. Kekuatiran ini khususnya berkenaan dengan menyeruaknya kembali sektarianisme dalam praktik politik yang dapat mengancam praktik demokrasi. Di sisi lain, media sosial dan platform kapitalismenya tampaknya justru bersesuaian dengan kepentingan kapitalis kecil yakni penyelenggara dan pendukung Aksi Bela Islam melalui perluasan 'fandom' Islamisme populer yang menjadi konsumen (pengguna media sosial). Dalam kenyataannya, kelompok-kelompok Islamis tidak hanya memperoleh dukungan publik tetapi juga logistik terutama dari kelompok-kelompok oposisi yang berlawanan dengan pemerintahan Joko Widodo dan mencoba mengganggu stabilitas pemerintahan yang sah melalui aksi ini. Kasus penodaan agama di Indonesia yang berakhir dengan kontroversi sebagaimana yang terjadi dalam kasus Ahok di tahun 2016 yang berakhir secara dramatis dengan dipenjarakannya Ahok pada bulan April 2017, sebenarnya bukan yang baru, terutama yang ikut diusung oleh FPI (Front Pembela Islam).

Namun, persebaran propaganda Islamis melalui konstruksi moralitas publik telah menciptakan ranah publik Muslim tertentu di mana media sosial juga digunakan untuk mengorganisir beragam acara dakwah seperti khotbah dan pengajian. Kegiatan yang menjadi bagian dari paket Aksi Bela Islam ini bukan hanya dipopulerkan di Jakarta yang menjadi lokus arena politik kontestasi pertarungan kepentingan politik dalam aksi-aksi tersebut. Tetapi juga diadakan di beberapa masjid-masjid tertentu di beberapa lokasi seperti di Jawa Barat, Jawa Tengah dan Yogyakarta, Sumatera Barat, Nusa Tenggara Barat, dan Sulawesi Selatan. Secara faktual, jejaring komunitas dan fandom Islamisme populer ini membentuk jaringan-jaringan 'Pembela Islam' tingkat nasional yang memiliki akses pada media sosial melalui aktivitas daring (online) dan bahkan memelihara pengorganisasian di tingkat komunitas melalui aktivitas luring (offline) yang lebih solid. Meskipun beberapa ormas Islam yang terlibat dalam Aksi Bela Islam berusaha untuk mewacanakan pentingnya 'persatuan umat Islam' melalui penerapan syariah, wacana tentang tema tersebut justru sulit menjadi suatu ketetapan yang solid (tidak fixed). Kenyataannya, mereka tidak selalu memiliki kesepakatan serupa tentang bentuk-bentuk syariah apa yang harus dipraktikkan atau diimplementasikan. Hal ini karena mereka sebenarnya berasal dari beragam spektrum ideologi Salafisme Islam yang berbeda-beda. Dengan kata lain, massa yang benar-benar bergabung dengan Aksi Bela Islam 
pun sesungguhnya berlatar belakang keragaman di dalam komunitas Muslim di Indonesia itu sendiri.

Tekanan sosial sebagai suatu kepentingan atas moralitas publik sudah lama berlangsung di Indonesia, dalam sejarahnya misalnya tentang perdebatan atas basis-basis fundamental ketatanegaraan - dalam perdebatan tentang konstruksi nasionalisme khususnya tentang perlu tidaknya menyantumkan ketentuan pemberlakuan syariat Islam bagi para penganutnya di dalam Pembukaan UUD 1945. Pada masa Orde Baru, kontruksi moralitas publik sebagai suatu tekanan politik nampak kuat pada pemberlakuan atas UU Perkawinan tahun 1974 yang terutama berdampak pada kontrol negara pada pernikahan yang bersifat multikultural. Konstruksi atas moralitas publik yang bersumber pada tekanan politik khususnya yang dikonstruksikan melalui bentuk-bentuk kepatuhan dan disiplin pada nilai-nilai Islam otentik kemudian berlangsung pada ruang sosial yang langsung berdampak dalam kehidupan privat. Sementara di sisi lain, keberadaan media dakwah khususnya di masa Reformasi mendapati bukan hanya ruang 'kontestasi politik' tetapi sekaligus 'ruang pamer' (display) tentang kebudayaan yang secara material dianggap sebagai merepresentasikan 'Islam otentik' melalui kebaharuan gaya hidup yang moderen. Dalam konteks seperti itulah, cara-cara mengkonstruksi identitas Muslim juga berkenaan dengan strategi meliyankan - othering - di mana media mainstream ikut memfasilitasi suatu 'gaya hidup alternatif' yang menampilkan bentuk-bentuk keshalehan personal Muslim yang bersifat formal - dan dilegitimasikan di dalam ruang publik dalam kehidupan sehari-hari di Indonesia. Kontestasi atas strategi meliyankan inilah yang acapkali selalu 'dimunculkan' sebagai suatu bentuk kepanikan moral - khususnya pada momentum tertentu dimana berdampak langsung dalam struktur dan kekuasaan hierarki politik di Indonesia, misalnya pada saat berlangsungnya Pemilu, Pilpres, atau bahkan Pilkada. Tidak mengherankan jika isu tentang keshalehan personal menjadi 'isu politik yang selalu digoreng' dalam setiap momen Pemilu tersebut.

Kemunculan media sosial dan penetrasi internet dalam kehidupan sehari-hari masyarakat di Indonesia juga semakin memperluas sekaligus mempolarisasikan ruang publik Muslim di Indonesia sebagai suatu konsekuensi atas strategi kampanye dakwah yang bersifat politis - meliyankan - sekaligus juga sebagai konsekuensi atas terbentuknya - kantong-kantong algoritmis melalui media sosial - yang mempolarisasikan para netizen (pengguna internet dan media sosial) di mana interaksi sosialnya dipengaruhi oleh dukungan politis yang dikonstruksikan melalui media sosial. Dalam kasus Pilpres 2014 misalnya, 
polarisasi yang menggunakan strategi 'meliyankan' juga berlangsung di antara para kubu pendukung kedua Capres. Praktik semacam ini meskipun bukan hal yang baru dalam kontestasi demokrasi politik di Indonesia, tetapi mendapati kerumitan dan berdampak pada mobilisasi dukungan massa secara lebih cepat dikarenakan difasilitasi melalui medium teknologi baru seperti melalui media sosial. Percepatan menjadi penanda tersendiri bagi berlangsungnya 'narasi bergerak' (shifting narratives) tentang identitas keshalehan dan otentisitas praktik keislaman - di mana rujukan melalui tafsir suci baik melalui ayat-ayat al Qur'an dan hadits digunakan untuk membingkai suatu argumen atau retorika meliyankan argumen atau bahkan meliyankan identitas lain, baik yang berasal dari kemajemukan (pluralitas) publik luas maupun yang berasal dari keragaman (multikulturalitas) dalam masyarakat Muslim sendiri - melalui narasi yang dimunculkan dengan menggunakan konteks kekinian. Dalam pengertian semacam inilah, penguasaan atas media yang secara populer memiliki pemirsa luas menjadi medium strategis bagi pewacanaan dominan tentang tafsir atas otentisitas Islam oleh suatu kelompok tertentu (terutama oleh kelompokkelompok Islamis) melalui narasi-narasi kebaharuan yang bersifat kontekstual tentang 'moralitas publik'.

\section{Penutup: Komodifikasi Islam di Era Neoliberalisme}

Dalam era neoliberalisme, agama kini tidak lagi menjalankan fungsi sosialnya yang bersifat 'sakral' - hal ini nampak dalam persekutuan antara simbol dan nilai-nilai kesalehan diri yang dapat dikonversi sebagai 'materi' yang dapat dipertukarkan untuk mencapai keuntungan maksimal. Di sisi lain, terkikisnya nasionalisme telah memberi peluang bagi gagasan-gagasan dan praktik yang besifat transnasional, termasuk persekutuan antara Islamisme dan kapitalisme neoliberal di dalam keseharian hidup kaum Muslim, bukan hanya di Indonesia, bahkan hampir di seluruh dunia, baik di dalam masyarakat mayoritas Muslim, maupun dimana masyarakat Muslim menjadi minoritas. Politik identitas menjadi sarana signifikan didalam mediatisasi dakwah yang dapat dimanipulasi bagi kepentingan agenda politik partisan atau bahkan keuntungan kapitalis. Di Barat, konsumerisme (praktik mengkonsumsi untuk kepuasan diri dan simbol status kelas sosial) sudah lama mapan,jauh sebelum neoliberal kapitalisme dipraktikkan (Gauthier, 2014). Neoliberalisme dimulai pada awal tahun 1980an dimana ketegangan blok Barat (negara-negara industri kapitalis) dan blok Timur (negara-negara otokratis sosialis) menemui momentum kesepakatan untuk mencairkan ketegangan dengan membuka sekat perdagangan dunia antar negara dan membentuk suatu sistem tunggal bagi perdagangan bebas. 
Perdagangan bebas ini bahkan bukan hanya berlaku atas komoditi yang secara konkrit bersifat 'material', melainkan juga pada pendefinisian bentuk-bentuk komoditi berupa jasa (services).

Dalam perkembangannya, neoliberalisme telah mengkonversi beragam nilainilai di ruang privat sebagai bentuk-bentuk jasa, bahkan simbol dan pengetahuan sebagai 'komoditas baru' yang dapat saling dipertukarkan untuk keuntungan maksimal (maximizing profits). Dalam konteks ini, menurut Francois Gauthier (2014), neoliberalisme telah mengubah ruang lingkup lingkungan (environment) agama dari "atas" (melalui hieraki institusional) - di dalam mengelola sumber daya manusia dan upaya pengkondisian pelembagaan agama melalui kompetisi yang bersifat memaksimalkan efisiensi dan keuntungan. Mediatisasi dakwah, karenanya, sebagaimana mediatisasi misi-misi agama-agama lain, misalnya agama Kristen di Amerika Serikat, menggunakan strategi budaya populer dan menjadi bagian yang tidak terpisahkan dari reproduksi sosial dan ekonomi yang dijalankan melalui logika kapitalisme neoliberal semacam ini. Dengan kata lain, komodifikasi Islam dianggap sebagai suatu kelumrahan - suatu normalisasi yang dijalankan di dalam kehidupan sehari-hari khususnya melalui mediatisasi dakwah yang didukung oleh perkembangan teknologi media dan komunikasi.

Mediatisasi dakwah secara historis di Indonesia menunjukkan bahwa perluasan ranah publik Muslim melalui konstruksi pewacanaan moralitas publik bukan hanya berdampak pada terbentuknya komunitas melainkan juga pada pembentukan konstituensi politik dan bahkan pasar identitas Islami. Hal ini dimungkinkan karena sistem ekonomi dan politik yang berlangsung di dalam praktik neoliberal kapitalisme hampir dapat dipastikan telah berampak pula pada tumbuhnya budaya konsumsi (consumer culture) termasuk pada bagaimana Islam sebagai suatu ajaran moral dan praktik sosial dikomodifikasikan. Komodifikasi ini bukan hanya mengabdi pada kepentingan yang bersifat ideologis atau politis semata, melainkan bahkan mengabdi pada kepentingan perluasan pasar itu sendiri. Globalisasi telah memungkinkan bagaimana transmisi ideologi-ideologi Islamisme bersemai di Indonesia dan menantang otoritas kelembagaan agama Islam yang sebelumnya telah mapan. Melalui globalisasi pula, praktik perdagangan untuk mendapatkan keuntungan maksimal telah mengkonversi segala sesuatu termasuk nilai (yang bersifat abstrak) sehingga dapat diubah sebagai 'komoditas' yang dapat dipertukarkan melalui transaksi yang melibatkan upaya memperoleh profit atau keuntungan secara material. Pola-pola keberagamaan kaum Muslim di Indonesia kini khususnya semenjak masa Reformasi semakin menunjukkan pola-pola 
kesalehan untuk pencapaian kepuasan diri semata yang cenderung bersifat individual. Pengajaran agama Islam lebih banyak diterima oleh publik Muslim di Indonesia melalui agensi yang bersifat tersier, di mana tujuan memperoleh 'jawaban spiritual' yang bersifat instan dan praktis justru dipopulerkan oleh sekelompok orang atau generasi yang memperoleh pengetahuan agama Islam melalui kegiatan agama yang berada di luar kelembagaan otoritas resmi seperti pesantren misalnya. Dalam konteks semacam ini, gerakan dakwah melalui strategi Islamisme populer telah sukses mengubah landskap sosial budaya ranah Muslim di Indonesia selama lebih dari dua dekade lamanya.

Mediatisasi dakwah khusunya di masa Reformasi melalui setidaknya empat mekanisme atau prosedur retoris melalui konstruksi moralitas publik. Pertama, melalui promosi atas identitas keislaman secara formal di ruang publik khususnya melalui budaya populer. Kedua, melalui perluasan pemirsa bagi ruang publik Muslim melalui dakwah populer baik melalui media mainstream maupun media sosial secara khusus mentargetkan kaum perempuan dan generasi muda sebagai konsumer bagi media-media Islam tertentu yang mempromosikan bentuk-bentuk keshalehan personal secara formal. Ketiga, melalui pewacanaan mengenai moralitas publik sebagai kelanjutan dari strategi meliyankan dalam merespon kemajemukan (pluralitas) di Indonesia yang telah berlangsung sejak bahkan di masa awal kebangkitan nasional (masa kolonial) dengan upaya untuk melegitimasi kondisi kontekstual di hari ini secara ambigu, misalnya dengan mewacanakan pentingnya syariah Islam, kepemimpinan kaum Muslim, tetapi secara ambigu tetap membingkai wacana tentang NKRI - misalnya sebagai wacana tanding akibat berlangsungnya polarisasi Islam liberal dan Islam radikal dalam pencitraan mengenai Islam di media-media mainstream yang sekuler. Keempat, melalui media sosial yang difungsikan untuk memobilisasi dukungan massa yang luas dan mengkampanyekan kegiatan-kegiatan yang dilakukan di dalam basis-basis komunitas sebagai strategi untuk merespon keragaman (multikulturalitas) dalam masyarakat Muslim di Indonesia - sebagaimana yang ditunjukkan dalam Aksi Bela Islam yang didukung oleh berbagai macam ormasormas Islam, kelompok-kelompok majelis taklim, dan beberapa pesantren yang sesungguhnya memiliki 'varian' latar belakang keragaman ideologi Islam politiknya. Keempat mekanisme inilah yang membentuk konstruksi mengenai moralitas publik tentang 'Islam yang otentik yang wacananya secara hegemonik' mencerminkan simbiosis antara Islam politik dan Islam sebagai gaya hidup di Indonesia hari ini. 


\section{Daftar Pustaka}

Ambrust, Walter. 2000. "Introduction", in Ambrust (ed), Mass Mediations: New Approaches to Popular Culture in the Middle East and Beyond. Berkeley: University California Press.

Bourdieu, Pierre. 1984. Distinction: A Social Critique of the Judgement of Taste (Transl. Nice, Richard). London: Routledge and Keagan Paul.

Eickelman, Dale and Anderson, Jon. 2003. New Media in The Muslim World: The Emerging Public Sphere. Bloomington and Indianapolis: Indiana University Press.

Fealy, Greg. 2008. "Consuming Islam: Commodified Religion and Aspirational Piety in Indonesia". In Fealy and White (eds). Expressing Isalm: Religious Life and Politics in Indonesia. Singapore: ISEAS.

Feener, Michael. 2007. Muslim Legal Thought in Modern Indonesia. Cambridge: Cambridge University Press

Gauthier, Francois. 2014. "Religion, Media, and the Dynamic of Consumerism in the Global Societies.” In Granholm, Kennet et.al (eds). Religion, Media and Social Changes. New York and London: Routledge.

Hefner, Robert. 1997. "Print Islam: Mass Media and Ideological Rivalries Among Indonesian Muslims", Indonesia 64: 76-103.

Hirschkind, Charles. 2006. Ethical Soundscape: Cassette Sermons and Islamic Counter-publics. New York: Columbia University Press.

Hrair, Dekmejian, R. 1980. "The Anatomy of Islamic Revival: Legitimacy, Crises, Ethnic Conflict and the Search for Islamic Alternatives." Middle East Journal 34 (Winter): 1-5.

Kaptein, Nico. 2009. "Southeast Asian Debates and the Middle Eastern Inspiration”, in Tagliacozzo, Eric (ed), Southeast Asia and the Middle East: Islam, Movement, and the Longue Duree. Singapore: NUS-Press.

Kellner, Douglas. 1995. Cultural Studies, Identities and Politics between the Modern and Postmodern. London: Routledge.

Laffan, Michael. 2011. The Making of Indonesian Islam: Orientalism and the Narration of a Sufi Past. Princeton and Oxford: Princeton University Press.

Lapidus, Ira Marvin. 2002. A History of Islamic Societies (2nd Edition). Cambridge: Cambridge University Press.

Madinier, Remmy. 2015. Islam and Politics in Indonesia: The Masyumi Party between Democracy and Integralism. Singapore: NUS Press.

Meyer, Birgit. 2009. "Introduction”. In Meyer (ed). Aesthetic Formation: Media, Religion and the Senses. New York: Palgrave MacMillan: 3-29. 
Pamungkas, ArieSetyaningrum. 2015.a. "The Dakwah Media in Post Suharto Indonesia: From Politics of Identity to Popular Culture (the case of Ummi)”. PhD Thesis. Humbolt University of Berlin. DOI: 10.18452/17136 (Accessed on March 20, 2015).

Pamungkas, Arie Setyaningrum, 2017.b. "Membela Islam? Dakwah, Konstruksi Moralitas dan Ruang Publik Muslim dalam Sejarah Media Islam di Indonesia.” In Sri Margana, Siti Utami Dewi Ningrum, Abmi Handayani (eds). Agama dan Negara di Indonesia: Pergulatan Pemikiran dan Ketokohan. Yogyakarta: Penerbit Ombak.

Salvatore, Armando and Levine, Mark. 2005. Religion, Social Practice and Contested Hegemonies: Reconstructing Public Sphere in Muslim Majority Societies. NY: Palgrave McMillan

Van Bruinessen, Martin. 2002. "Genealogies of Islamic Radicalism in Post Suharto Indonesia”. Southeast Asian Research 10 (2)

Yavuz, Hakan. 2004. "Opportunity Spaces, Identity and Islamic Meaning in Turkey.” In Wictorowicz (ed). Islamic Activism: A Social Movement Theory Approach. Bloomington and Indianapolis: Indiana University Press.

Weintraub, Andrew. 2011. "Introduction: the Study of Islam and Popular Culture in Indonesia and Malaysia." In Weintraub (ed). Islam and Popular Culture in Indonesia and Malaysia. London: Routledge. 